\title{
Antioxidant and a-glucosidase inhibitory effects of ethanolic extract of Ainsliaea acerifolia and organic solvent-soluble fractions
}

\author{
Eun-Woo Lee 1 , Taewan Kim², Hyun-Seok Kim², Youn-Moon Park ${ }^{2}$, Seong-Ho Kim³ \\ Moo-Hyeog $\mathrm{Im}^{3}$, Jae Hoon Kwak ${ }^{4}$, Tae Hoon Kim ${ }^{3 *}$ \\ ${ }^{1}$ Department of Life Science and Biotechnology, Dongeui University, Busan 614-714, Korea \\ ${ }^{2}$ Department of Food Science and Biotechnology, Andong National University, Andong 760-749, Korea \\ ${ }^{3}$ Department of Food Science and Biotechnology, Daegu University, Gyeongsan 712-714, Korea \\ ${ }^{4}$ Faculty of Biotechnology Convergence, Daegu Haany University, Gyeongsan 712-715, Korea
}

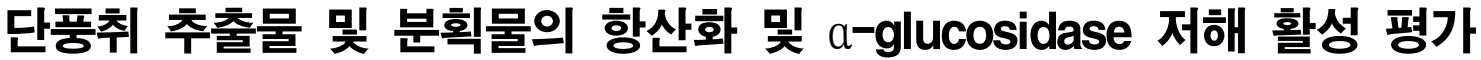

\author{
이은우 ${ }^{1} \cdot$ 김태완 ${ }^{2} \cdot$ 김현석 $^{2} \cdot$ 박윤문 $^{2} \cdot$ 김성호 $^{3} \cdot$ 임무혁 $^{3} \cdot$ 곽재훈 $^{4}$. 김태훈 ${ }^{3 *}$ \\ ${ }^{1}$ 동의대학교 생명응용학과, ${ }^{2}$ 안동대학교 식품생명공학과, ${ }^{3}$ 대구대학교 식품공학과, \\ ${ }^{4}$ 대구한의대학교 바이오산업융합학부
}

\begin{abstract}
Among the naturally occurring antioxidants, polyphenols are widely distributed in various fruits, vegetables, wines, juices, and plant-based dietary sources and divided into several subclasses that included phenolic acid, flavonoids, stilbenes, and lignans. As part of our continuing search for bioactive food ingredients, the antioxidant and a-glucosidase inhibitory activities of the aqueous ethanolic extract from the aerial parts of Ainsliaea acerifolia were investigated in vitro. The antioxidant properties were evaluated via radical scavenging assays using 1,1-diphenyl- 2-picrylhydrazyl (DPPH) and 2,2'-azino-bis (3-ethylbenzothiazoline-6-sulphonic acid) (ABTS ${ }^{+}$) radicals. In addition, the anti-diabetic effect of $A$. acerifolia extracts was tested via a-glucosidase inhibitory assay. Furthermore, the total phenolic contents were determined using a spectrophotometric method. All the tested samples showed dose-dependent radical scavenging and a-glucosidase inhibitory activities. In particularly, the a-glucosidase inhibitory and radical scavenging properties of the ethyl acetate (EtOAc)-soluble portion from the aerial parts of the A. acerifolia were higher than those of the other solvent-soluble portions. These results suggest that $A$. acerifolia could be considered a new potential source of natural antioxidants and antidiabetic ingredients. More systematic investigation of the aerial parts of $A$. acerifolia will be performed for the further development of anti-oxidative and antidiabetic drugs.
\end{abstract}

Key words : Ainsliaea acerifolia, antioxidant activity, DPPH, ABTS $^{+}$, a-glucosidase

\section{서 론}

각종 퇴행성 질환 및 생활 습관성 질병이 현대인들의 건강을 위협하고 있으며, 이는 과도한 산화적 스트레스에

*Corresponding author. E-mail : skyey7@daegu.ac.kr Phone : 82-53-850-6533, Fax : 82-53-850-6539

Received 5 September 2014; Revised 13 November 2014; Accepted 5 December 2014.

Copyright (c) The Korean Society of Food Preservation. All rights reserved.
대한 노출이 그 원인이다. 인체는 산화촉진물질과 산화 억 제물질이 균형을 이루어 자유라디칼의 생산과 항산화 방어 체계가 유지 되는데 자외선, 흡연, 매연, 약물, 스트레스, 방사선 등의 요인은 그 균형을 깨뜨린다. 이로 인해 과도하 게 생성된 superoxide, nitric oxide, nitrogen dioxide, hydroxyl, peroxynitrite 등과 같은 활성산소종(reactive oxygen species, ROS)은 산화적 스트레스를 일으키며 세포 구성성분인 지질, 단백질, 당, DNA 등에 비선택적, 비가역 적 파괴를 촉진 한다 $(1,2)$. 이러한 작용은 노화를 비롯해 암, 뇌질환, 심혈관계질환, 피부질환 등의 각종 질병의 원인 
이 된다 $(3,4)$. 체 내에서 ROS나 자유라디칼을 중화시켜 노 화방지, 성인병 예방 등의 기능을 하는 성분을 항산화물질 이라고 하며, butylated hydroxy anisol(BHA), butylated hydroxy toluene(BHT) 등의 합성 항산화제가 개발되어 사 용되었으나 $(5,6)$, 이들 합성항산화제는 암, 지질대사 불균 형 등의 부작용이 발견되어 사용제한을 권고하고 있다(7). 최근 항산화에 대한 대중의 관심이 높아짐에 따라 평소 생활에서 항산화물질이 풍부한 과일이나 견과류 등의 천연 자원을 통한 천연 항산화제의 섭취가 늘고 있으며 최근 연구보고에 따르면 블루베리, 샐러리, 감귤 및 포도 등에도 항산화 물질이 다량 포함되어 있음이 알려져 있다(8).

최근 경제성장 및 생활수준의 향상으로 인한 식습관의 변화가 가속화됨에 따라 만성 대사성 질환 중 하나인 당뇨 병이 증가하고 있는데, 전 세계 당뇨인구는 급격히 증가하 고 있을 뿐만 아니라 발병연령도 점차 낮아져 앞으로는 더 많은 인구가 당뇨병으로 인해 고통 받을 것으로 예측된 다(9). 당뇨병은 크게 두 가지로 나뉘며 제1형은 췌장 베타 세포의 병변에 따른 인슐린 결핍으로 인한 인슐린 의존성, 제 2 형은 인슐린 저항성으로 인한 인슐린 비의존성 당뇨로 정의된다 $(10,11)$. 일반적으로 당뇨병과 항산화작용은 서로 밀접한 연관이 있음을 최근 연구에서 시사했는데 이는 췌장 베타세포의 손상이 산화적 스트레스에 의해 발생되고 이것 이 곧 인슐린 분비감소로 이어져 항산화 물질이 당뇨병 개선에 관련하는 것으로 밝히고 있다(12). 한편 a-glucosidase 는 장의 소장점막에 존재하는 당분해효소로서 이를 저해하 면 탄수화물의 소화를 방해하여 소장에서의 흡수가 지연되 므로 식후 급격한 혈당상승을 막아준다(13). 대표적인 a -glucosidase 저해제는 acarbose 및 voglibose가 시판되고 있 으나 이들을 장기 복용할 경우 내성 및 각종 부작용을 야기 할 수 있어 사용이 제한된다 $(14,15)$. 따라서 보다 안전하며 효능이 우수한 천연 기능성 소재의 탐색이 필요한 실정이다.

단풍취(Ainsliaea acerifolia)는 국화과(Compositae)의 다 년초로서 어린잎은 식용으로 쓰이며 국내에 흔히 자생한 다. 중국에서 Ainsliaea속 식물 7종이 예로부터 관절통, 근육 통, 항염증 등에 이용되어 왔으며(16) 지금까지 밝혀진 단풍 취의 성분으로는 sesquiterpene lactone 및 friedelane 유도체 등이 있다(17-20).

본 연구에서는 단풍취의 $70 \%$ 에탄올 추출물 및 각 분획 물에 대하여 항산화 및 항당뇨 활성을 평가에 활용한 라디 칼 및 a-glucosidase 저해 활성평가에서 우수한 효능을 확인 하였기에 그 결과를 보고하고자 한다.

\section{재료 및 방법}

재 료

본 실험에 시료로 사용한 단풍취(Ainsliaea acerifolia)는
경북 영양군 수비면에서 2013년도 5월에 채취된 신선한 단풍취를 사용하였으며, 표본시료는 대구한의대학교의 바 이오산업융합부 천연물화학실험실에 보관하고 있다.

\section{추출물의 제조 및 분획}

신선한 단풍취 $5.0 \mathrm{~kg}$ 을 $70 \%$ 에탄올로 침지추출을 4회 반복하여 필터 한 후 농축하였다. 얻어진 단풍취 $70 \%$ 에탄 올 추출물 $(401.0 \mathrm{~g})$ 에 대해 물에 현탁하여 저극성 용매인 $n$-Haxane으로 먼저 추출한 후 수층을 다시 ethyl acetate(EtOAc)와 $n$-butyl alcohol $(n-\mathrm{BuOH})$ 을 이용하여 각 각 순차적으로 5 회 분획하여 추출하였다. 각 용매추출 분획 을 감압 농축하여 건조 시킨 후 각각 $n$-hexane 가용분획 $(73.8 \mathrm{~g}), \mathrm{EtOAc}$ 가용분획 $(56.0 \mathrm{~g}), n-\mathrm{BuOH}$ 가용분획(27.9 $\mathrm{g}), \mathrm{H}_{2} \mathrm{O}$ 가용분획 $(186.0 \mathrm{~g})$ 을 각각 얻었으며 각 분획물을 대상으로 라디칼 소거능 및 a-glucosidase 저해능 평가를 수행하였다.

\section{$\mathrm{DPPH}$ 라디칼소거능 측정}

단풍취 $70 \%$ 에탄올 추출물의 전자공여능은 Blois 방법 (21)에 따라 측정하였다. 각 시료용액에 $120 \mu \mathrm{L}$ 에 $0.45 \mathrm{mM}$ 의 희석한 1,1-diphenyl-2-picrylhydrazyl(DPPH) 용액 $60 \mu \mathrm{L}$ 을 넣고 교반한 후 15 분간 방치한 다음 $517 \mathrm{~nm}$ 에서 흡광도 를 측정하였다. 전자공여능은 시료용액의 첨가군과 흡광도 차이를 백분율로 나타내었다.

\section{$\mathrm{ABTS}^{+}$라디칼 소거능 측정}

단풍취 $70 \%$ 에탄올 추출물의 2,2'-azinobis-3-ethylbenzothiazoline-6-sulfonic acid(ABTS) radical 소거능을 $\operatorname{Re}(22)$ 의 방법을 변형하여 다음과 같이 측정하였다. $7 \mathrm{mM}$ $\mathrm{ABTS}$ (in water)와 $2.4 \mathrm{mM} \mathrm{K}_{2} \mathrm{O}_{8} \mathrm{~S}_{2}$ 동량을 혼합 후 실온, 암소 에서 12 시간 방치하여 라디칼의 생성을 유도한 후 $\mathrm{ABTS}^{+}$ 라디칼 용액을 희석하여 $734 \mathrm{~nm}$ 에서 흡광도 값이 $0.7 \sim 0.8$ 정도가 되도록 희석한 후 사용하였다. 희석한 $\mathrm{ABTS}^{+}$라디 칼 용액 $100 \mu \mathrm{L}$ 와 생약 추출액 $100 \mu \mathrm{L}$ 을 혼합하여 실온에서 7 분간 반응시킨 후 $734 \mathrm{~nm}$ 에서 흡광도를 측정하였다. 이때 positive control로는 (+)-catechin을 사용하였으며 결과는 시 료를 처리하지 않은 군에 대한 \%로 표시하였다.

\section{$a^{-g l u c o s i d a s e}$ 저해활성 측정}

a-glucosidase 저해능은 $\operatorname{Eom}(23)$ 등이 행한 방법을 변형 하여 효소-기질반응을 이용한 분광학적 방법으로 측정하였 다. 즉, $1 \mathrm{U} / \mathrm{mL}$ a-glucosidase $90 \mu \mathrm{L}$ 에 시료 혹은 $0.1 \mathrm{M}$ sodium phosphate buffer(pH 6.8) $10 \mu \mathrm{L}$ 를 첨가하여 혼합한 후 $37^{\circ} \mathrm{C}$ 에서 15 분 동안 반응시킨다. 반응 후 기질인 $1 \mathrm{mM}$ $p$-NPG $100 \mu \mathrm{L}$ 를 첨가한 후 5 분간 반응시키고 $405 \mathrm{~nm}$ 에서 ELISA reader(Infinite F200, Tecan Austria GmBH, Grödig, Austria)를 이용하여 흡광도를 측정함으로써 기질로부터 
유리되어 나오는 p-nitriphenol을 측정하였다. 양성대조군 으로는 a-glucosidase 저해제로 알려진 acarbose를 사용하였 으며 a-glucosidase 저해활성은 시료용액의 첨가군과 무첨 가군의 흡광도 감소율로 나타내었다.

\section{총페놀성 화합물 함량 평가}

총 페놀성 화합물의 함량은 Folin-Denis 방법(24)에 따라 측정하였으며, 추출물 혹은 분획물을 $1.0 \mathrm{mg} / \mathrm{mL}$ 농도로 조제한 후, 시료 $50 \mu \mathrm{L}$ 와 Folin-Denis 시액 $50 \mu \mathrm{L}, 0.7 \mathrm{M}$ 탄산나트륨 포화용액 $50 \mu \mathrm{L}$ 를 차례로 넣은 다음 이것을 잘 혼합하여 실온에서 60 분 방치한 후 UV/VIS 분광광도계 (Cary 50, Varian, Melbourne, Australia)로 $750 \mathrm{~nm}$ 에서 흡광 도를 측정하였으며, 표준물질은 gallic acid를 이용하여 표 준곡선을 작성하여 양을 환산하였다.

\section{결과 및 고찰}

$\mathrm{DPPH}$ 라디칼 소거활성

보라색을 띄는 비교적 안정한 유리라디칼인 $\mathrm{DPPH}$ 는, 그 자체가 홀수전자를 가지고 있어 $517 \mathrm{~nm}$ 에서 강한 흡광 도를 나타낸다. 따라서 항산화능이 있는 물질과 반응하게 되면 안정한 형태로 돌아가면서 색이 탈색되고 흡광도 값이 감소한다(25). Table 1에서 나타낸 것처럼 단풍취 $70 \%$ 에탄 올 추출물 및 각 유기용매 분획에 대해서 라디칼 소거능을 평가한 결과, $125 \mathrm{mg} / \mathrm{mL}$ 의 농도에서 $70 \%$ 에탄올 추출물이 $66.3 \%$ 의 라디칼 소거능을 나타내었으며, 특히 EtOAc 분획 물이 $125 \mathrm{mg} / \mathrm{mL}$ 의 농도에서 $77.6 \%$ 의 가장 우수한 라디칼 소거능을 나타내었고, 이 결과는 positive control로 사용된 천연 항산화 성분으로 잘 알려져 있는 (+)-catechin과 같은 농도에서 유사한 활성을 나타냄을 확인하였다. $n-\mathrm{BuOH}$ 분 획물 또한 $125 \mathrm{mg} / \mathrm{mL}$ 의 농도에서 $68.4 \%$ 의 우수한 라디칼 소거능을 나타내었으며, $\mathrm{H}_{2} \mathrm{O}$ 층과 $n$-Hexane 분획물에서는 각각 $43.7 \%, 7.3 \%$ 비교적 약한 라디칼 소거능을 나타내었다.

Table 1. DPPH radical scavenging activity of the $70 \%$ ethanolic extract of Ainsliaea acerifolia and its $n$-hexane, EtOAc-, $n$-BuOH-, and $\mathrm{H}_{2} \mathrm{O}$-soluble portions

\begin{tabular}{|c|c|c|c|c|c|c|c|}
\hline \multirow{2}{*}{ Conc. (mg/mL) } & \multicolumn{6}{|c|}{ Inhibition (\%) } & \multirow{2}{*}{$\begin{array}{c}\mathrm{IC}_{50} \\
(\mu \mathrm{g} / \mathrm{mL})\end{array}$} \\
\hline & 1000 & 500 & 250 & 125 & 62.5 & 31.3 & \\
\hline $70 \%$ EtOH ext. & 90.2 & 89.0 & 87.6 & 66.3 & 40.8 & 19.8 & $81.4 \pm 7.4$ \\
\hline n-Hexane layer & 49.9 & 34.0 & 16.8 & 7.3 & 0.7 & 0.0 & $>1000$ \\
\hline EtOAc layer & 94.0 & 93.2 & 89.4 & 77.6 & 55.6 & 35.3 & $51.4 \pm 3.0$ \\
\hline$n-\mathrm{BuOH}$ layer & 93.9 & 91.8 & 85.1 & 68.4 & 46.0 & 27.4 & $70.1 \pm 2.7$ \\
\hline $\mathrm{H}_{2} \mathrm{O}$ layer & 84.1 & 74.9 & 61.2 & 43.7 & 24.3 & 7.3 & $180.3 \pm 13.7$ \\
\hline$(+)$-Catechin ${ }^{1)}$ & 92.2 & 88.1 & 87.8 & 87.6 & 83.8 & 75.0 & $13.0 \pm 1.0$ \\
\hline
\end{tabular}

${ }^{1)}$ Used as a positive control.

\section{총페놀 화합물 함량}

단풍취 추출물 및 각 분획물에 함유하고 있는 총페놀성 화합물의 함량을 Table 4 에 나타내었으며, EtOAc 분획물이 $1 \mathrm{~g}$ 당 $22.4 \mathrm{mg}$ 의 페놀성 화합물을 함유하는 것으로 나타났 으며, $n-\mathrm{BuOH}$ 분획물이 $20.1 \mathrm{mg}, \mathrm{H}_{2} \mathrm{O}$ 층에서는 $1 \mathrm{~g}$ 당 4.3 $\mathrm{mg}$ 의 페놀성 화합물의 함량이 확인되었다. 또한 n-hexane 분획물이 $2.2 \mathrm{mg}$ 의 상대적으로 낮은 페놀 함유량을 나타내 는 것으로 분석되었다. 이상의 결과는 단풍취 추출물의 $\mathrm{DPPH}$ 라디칼 소거능은 Table 1 및 2에서 나타낸 것처럼 페놀성 화합물의 함량이 상대적으로 높은 EtOAc 및 $n \mathrm{BuOH}$ 층에서 상대적으로 높은 것을 확인할 수 있었으며, $\mathrm{DPPH}$ 라디칼 소거능과 총 페놀성 화합물 함량사이에는 밀접한 상관관계가 있다는 보고(26)와도 일치하는 결과였 다.

Table 2. Total phenolic contents of the ethanolic extract and organic solvent fractions of Ainsliaea acerifolia

\begin{tabular}{lcc}
\hline \multicolumn{1}{c}{ Samples } & Extraction yield $(\mathrm{g} / 100 \mathrm{~g})$ & Phenolic contents $(\mathrm{mg} / \mathrm{g})$ \\
\hline $70 \%$ EtOH ext. & $8.0 \pm 1.1^{1)}$ & $18.1 \pm 1.6$ \\
$n$-Hexane layer & $18.4 \pm 1.2$ & $2.2 \pm 0.3$ \\
EtOAc layer & $14.0 \pm 1.3$ & $22.4 \pm 2.1$ \\
$n$-BuOH layer & $6.9 \pm 0.3$ & $20.1 \pm 2.5$ \\
$\mathrm{H}_{2} \mathrm{O}$ layer & $46.5 \pm .2 .5$ & $4.3 \pm 0.5$ \\
\hline
\end{tabular}

${ }^{1)}$ The data represent the mean $\pm \mathrm{SD}$ of the three replications.

\section{$\mathrm{ABTS}^{+}$라디칼 소거능 측정}

$\mathrm{ABTS}^{+}$라디칼 소거능은 시료가 항산화력에 의해 $\mathrm{ABTS}^{+}$ 이 소거되어 본래의 청록색이 탈색되는 정도를 측정하는 방법으로 천연소재의 항산화활성물질 개발을 위한 연구에 많이 이용되고 있다(27). 그 결과 Table 2에서 나타낸 것처 럼 단풍취 $70 \%$ 에탄올 추출물은 $125 \mathrm{mg} / \mathrm{mL}$ 농도에서는 $89.8 \%$ 의 $\mathrm{ABTS}^{+}$라디칼 소거능을 나타냄을 확인하였으며, 각 분획물중에서도 특히 $\mathrm{EtOAc}$ 및 $n \mathrm{BuOH}$ 분획층이 125 $\mathrm{mg} / \mathrm{mL}$ 의 농도에서 $99.3 \%$ 및 $99.0 \%$ 의 매우 우수한 라디칼 소거능을 나타내었으며, 이는 positive control인 (+)-catechin의 활성에 상당하는 효능임을 확인하였다. EtOAc 분획층의 $62.5 \mathrm{mg} / \mathrm{mL}$ 의 농도에서 $99.1 \%, 31.3 \mathrm{mg} / \mathrm{mL}$ 의 농도에서 $86.0 \%$ 의 라디칼 소거능을 나타내어 유의적인 농도 의존적 성향을 보였다. 한편, $\mathrm{H}_{2} \mathrm{O}$ 분획층과 $n$-Hexane 분획층에서 는 상대적으로 낮은 라디칼소거 활성을 나타내었다. Table 4에서 나타낸 것처럼 총 페놀성 함량 상대적으로 높게 나타 난 $\mathrm{EtOAc}, n-\mathrm{BuOH}$ 층에서 $\mathrm{ABTS}^{+}$라디칼 소거 활성물질의 존재가 시사되었으며, 단풍취에 존재하는 sesquiterpene류 (17-20) 이외에 라디칼소거활성을 나타내는 물질의 존재에 대한 보고는 없으며, 특히 $\mathrm{EtOAc}$ 및 $n \mathrm{BuOH}$ 층에 존재하는 라디칼소거 활성물질의 동정이 필요하다고 사료된다. 


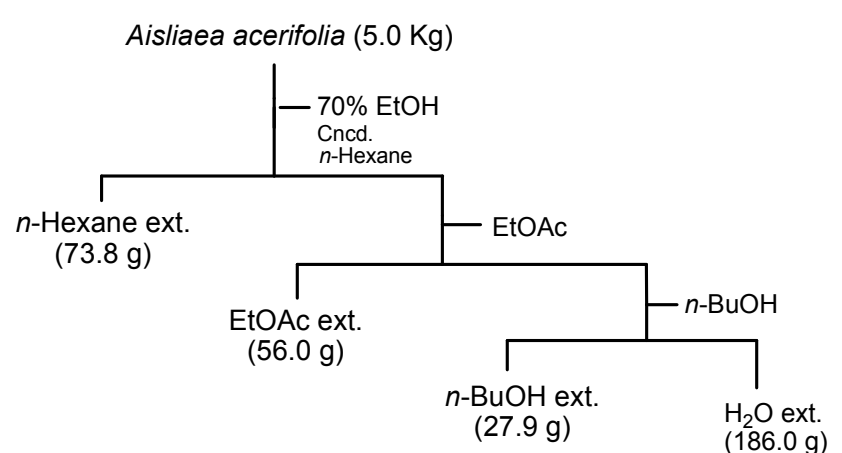

Fig. 1. Liquid-liquid partition of Aisliaea acerifolia.

Table 3. $\mathrm{ABTS}^{+}$radical scavenging activity of the ethanolic extract of Ainsliaea acerifolia and its $n$-hexane, EtOAc-, $n$-BuOH-, and $\mathrm{H}_{2} \mathrm{O}$-soluble portions

\begin{tabular}{lccccccc}
\hline \multirow{2}{*}{ Conc. (mg/mL) } & \multicolumn{9}{c}{ Inhibition (\%) } & \multicolumn{2}{c}{$\mathrm{IC}_{50}$} \\
& 1000 & 500 & 250 & 125 & 62.5 & 31.3 & $(\mathrm{\mu g} / \mathrm{mL})$ \\
\hline 70\% EtOH ext. & 99.1 & 99.3 & 99.2 & 89.8 & 75.0 & 46.3 & $34.3 \pm 0.9$ \\
n-Hexane layer & 94.6 & 70.8 & 40.4 & 20.6 & 12.6 & 4.7 & $291.0 \pm 20.1$ \\
EtOAc layer & 99.5 & 99.5 & 99.4 & 99.3 & 99.1 & 86.0 & $19.9 \pm 2.3$ \\
n-BuOH layer & 99.4 & 99.3 & 99.3 & 99.0 & 94.5 & 69.9 & $23.4 \pm 0.3$ \\
$\mathrm{H}_{2}$ O layer & 99.1 & 98.7 & 94.9 & 86.8 & 55.2 & 29.5 & $52.8 \pm 2.3$ \\
$(+)-$ Catechin $^{1)}$ & 99.9 & 99.9 & 99.9 & 99.8 & 99.7 & 99.6 & $2.3 \pm 0.2$ \\
\hline
\end{tabular}

${ }^{1)}$ Used as a positive control.

\section{a-Glucosidase 저해활성 측정}

Acarbose와 vogilbose 등은 섭취한 탄수화물을 단당류로 분해하는데 관여하는 효소인 a-glucosidase의 활성을 저해 하는 기전으로 연구 개발(28)되어 항당뇨를 목적으로 시판 된 대표적인 당뇨 치료제이다. 그러나 이들을 장기간 복용 할 경우 구토, 설사를 비롯한 복부팽만감 등의 부작용이 뒤따를 수 있으므로 보다 안전하면서 식후 혈당 강하의 효능이 있는 천연소재에 관한 연구의 필요성이 대두되고 있다(29). 본 연구에서 수행한 실험의 결과 단풍취 $70 \%$ 에탄올 추출물에서는 $500 \mu \mathrm{g} / \mathrm{mL}$ 일 때 $51.4 \%$ 의 효능을 나타 내었고, $\mathrm{EtOAc}$ 분획층과 $n \mathrm{BuOH}$ 가용분획은 각각 $98.5 \%$ 와 $82.0 \%$ 로 상대적으로 강한 활성을 나타났다. 양성대조구 인 acarbose의 $\mathrm{IC}_{50}$ 값과 비교해볼 때 $\mathrm{EtOAc}$ 가용분획은 $103.4 \pm 1.0$ 으로서 높은 효능을 나타내었다. 최근의 연구(30) 에 의하면 베트남산 도꼬마리(Xanthium strumarium) 열매 의 $\mathrm{IC}_{50}$ 값은 $35.0 \mu \mathrm{g} / \mathrm{mL}$, 차전초(Plantago asiatica) 지상부 의 $\mathrm{IC}_{50}$ 값은 $55.0 \mu \mathrm{g} / \mathrm{mL}$, 능소화과 오록실룸 인디쿰 (Oroxylum indicum) 심재의 $\mathrm{IC}_{50}$ 값은 $31.9 \mu \mathrm{g} / \mathrm{mL}$ 의 $\mathrm{a}$ -glucosidase의 활성을 나타내었으며 이들의 활성과 단풍취 의 EtOAc 가용부와의 상대적 효능 평가가 가능하며 향후 활성물질의 동정을 통한 활성기작 평가가 필요하다고 사료 된다.
Table 4. Inhibitory effects of the $70 \%$ ethanolic extract of $A$ aserifolia and its $n$-hexane, EtOAc-, $n$ - $\mathrm{BuOH}$-, and $\mathrm{H}_{2} \mathrm{O}$-soluble portions against a-glucosidase

\begin{tabular}{lccccccc}
\hline \multirow{2}{*}{ Conc. (mg/mL) } & \multicolumn{7}{c}{ Inhibition (\%) } \\
& 1000 & 500 & 250 & 100 & 50 & 10 & $(\mu \mathrm{g} / \mathrm{mL})$ \\
\hline 70\% EtOH ext. & 72.1 & 51.4 & 23.6 & 3.8 & 2.5 & 1.5 & $482.5 \pm 12.9$ \\
n-Hexane layer & 54.3 & 36.9 & 5.8 & 0.2 & 0.1 & 0.0 & $>500$ \\
EtOAc layer & 99.5 & 98.5 & 95.7 & 47.0 & 8.7 & 1.0 & $103.4 \pm 1.0$ \\
$n$-BuOH layer & 92.8 & 82.0 & 49.0 & 28.4 & 5.6 & 1.7 & $221.1 \pm 19.5$ \\
$\mathrm{H}_{2} \mathrm{O}$ layer & 82.8 & 71.0 & 57.2 & 35.1 & 11.6 & 3.2 & $203.2 \pm 16.8$ \\
Acarbose ${ }^{1)}$ & 67.9 & 50.6 & 43.1 & 37.8 & 5.7 & 3.5 & $501.1 \pm 17.5$ \\
\hline 1
\end{tabular}

${ }^{1)}$ Used as a positive control.

\section{요 약}

단풍취를 $70 \%$ 에탄올로 침지 추출하여 얻어진 추출물에 대해 n-hexane, EtOAc 및 $n-\mathrm{BuOH}$ 로 순차 용매 분획하였고, 얻어진 결과물에 대하여 $\mathrm{DPPH}$ 와 $\mathrm{ABTS}^{+}$radical 소거능 및 a-glucosidase 저해활성을 평가하였다. DPPH 라디칼 소 거능은 페놀성 화합물의 함량이 상대적으로 높은 EtOAc 층에서 $\mathrm{IC}_{50}$ 값이 $23.4 \pm 0.3 \mu \mathrm{g} / \mathrm{mL}$ 으로 강한 $\mathrm{DPPH}$ 라디칼 소거능을 확인하였고, 단풍취 추출물에 존재하는 페놀성 화합물과 라디칼 소거능과의 연관성을 시사하였다. 또한 $\mathrm{ABTS}^{+}$라디칼 소거능은 $\mathrm{EtOAc}$ 층의 $\mathrm{IC}_{50}$ 값이 $19.9 \pm 2.3$ $\mu \mathrm{g} / \mathrm{mL}, n-\mathrm{BuOH}$ 층이 $\mathrm{IC}_{50}$ 값이 $23.4 \pm 0.3 \mu \mathrm{g} / \mathrm{mL}$ 의 우수한 라디칼 소거활성이 확인 되었고, 강한 활성물질의 존재가 시사되었다. 또한, a-glucosidase 저해활성을 측정한 결과, 강한 $\mathrm{ABTS}^{+}$라디칼 소거능을 나타낸 $\mathrm{EtOAc}$ 층의 $\mathrm{IC}_{50}$ 은 $103.4 \pm 1.0 \mu \mathrm{g} / \mathrm{mL}$ 의 저해활성을 나타내었으며 이는 positive control인 acarbose에 비해 우수한 활성이었으며, 추출물 상 태의 시료를 단일물질로 정제할 경우 더욱 강한 효능의 화합물이 존재할 가능성을 시사하였다. 향후 이들 활성물 질 동정을 통한 활성 기작에 대한 연구가 필요하며 본 연구 결과는 보다 우수한 라디칼 소거능 및 a-glucosidase 저해능 을 가지는 새로운 기능성 식품소재 발굴을 위한 기초자료로 활용가능하리라 사료된다.

\section{감사의 글}

본 연구는 산림청 산림과학기술개발사업(S111313L050120) 의 지원 및 2014학년도 동의대학교 교내연구비(과제번호 2014AA279)의 지원으로 이루어 졌으며 이에 감사드립 니다. 


\section{References}

1. Videla LA, Fermandez V (1988) Biochemical aspects of cellular oxidative stress. Arch Biol Med Exp, 21, 85-92

2. Halliwell B, Aruoma OJ (1991) DNA damage by oxygen-derived species. FEBS Lett, 281, 9-19

3. Jennings PE, Barnett AH (1988) New approaches to the pathogenesis and treatment of diabetic microangiopathy. Diabetic Med, 5, 111-117

4. Shim JS, Kim SD, Kim TS, Kim KN (2005) Biological activities of flavonoid glycosides isolated from Angelica keiskei. Korean J Food Sci Technol, 37, 78-83

5. Farag RS, Badei AZMA, Hewedi FM, El-Baroty GSA (1989) Antioxidant activity of some spice essential oils on linoleic acid oxidation in aqueous media. J American Oil Chem Soc, 66, 792-799

6. Frei B (1994) National antioxidants in human health and disease, Academic Press, San Diego, p 44-55

7. Branen AL (1975) Toxicology and biochemistry of butylated hydroxy anisole and butylated hydroxy toluene. J Oil Chem Soc, 52, 59-62

8. Matsuoka A, Furuta A, Ozaki M, Fukuhara K, Miyata N (2001) Resveratrol, a naturally occurring polyphenol, induces sister chromatid exchanges in a Chinese hamster lung (CHL) cell line. Mutat Res, 107, 494-495

9. Rubin RR, Peyrot M (1999) Quality of life and diabetes. Diabetes Metab Res Rev, 15, 205-218

10. Lee SH, Lee JK, Kim IH (2012) Trends and perspectives in the development of antidiabetic drugs for type 2 diabetes mellitus. Korean J Microbiol Biotechnol, 40, 180-185

11. Lee EB, Na GH, Ryu CR, Cho MR (2004) The review on the study of diabetes mellitus in Oriental medicine journals. J Korean Orient Med, 25, 169-179

12. Schwarz K, Mertz W (1959) Chromium (III) and the glucose tolerance factor. Arch Biochem Biophys, 85, 292-295

13. Paul R, Jamie H, Phuong OT, Vincent P (2004) $\beta-C e l l$ glucose toxicity, lipotoxicity and chronic oxidative stress in type 2 diabetes. Diabetes, 53, 5119-5124

14. Tsujimoto T, Shioyama E, Moriya K, Kawaratani H, Shirai Y, Toyohara M, Mitoro A, Yamao J, Fujii H, Fukui $\mathrm{H}$ (2008) Pneumatosis cystoides intestinalis following alpha-glucosidase inhibitor treatment : a case report and review of the literature. World J Gastroenterol, 14, 6087-6092

15. Kihara Y, Ogami Y, Tabaru A, Unoki H, Otsuki M (1997)
Safe and effective treatment of diabetes mellitus associated with chronic liver diseases with an alpha-glucosidase inhibitor, acarbose. J Gastroenterol, 32, 777-782

16. Jung CM, Kwon HC, Choi SZ, Lee JH, Lee DJ, Ryu SN, Lee KR (2000) Phytochemical constituents of Ainsliaea acerifolia. Korean J Pharmacogn, 31, 125-129

17. Bohlmann F, Chen ZL (1982) Guaianolides from Ainsliaea fragrans. Phytochem, 21, 2120-2122

18. Adegawa S, Miyase T, Ueno A (1987) Sesquiterpene lactones from Diaspananthus uniflorus. Chem Pharm Bull, 35, 1479-1485

19. Miyase T, Ozaki H, Ueno A (1991) Sesquiterpene glycosides from Aisliaea cordifolia Franch. et Sav. Chem Pharm Bull, 39, 937-938

20. Jin H (1982) Studies on the constituents of Ainsliaea acerifolia Sch. -Bip. var. subapoda Nakai. Yakugaku Zasshi, 102, 911-922

21. Blois MS (1958) Antioxidant activity determination by the use of a stable free radical. Nature, 181, 1199-1200

22. Re R, Pellegrini N, Proteggente A, Pannala A, Yang M, Rice-Evans C (1999) Antioxidnt activity applying and improved ABTS radical cation decolorization assay. Free Radic Biol Med, 26, 1231-1237

23. Eom SH, Lee SH, Yoon NY, Jung WK, Jeon YJ, Kim SK, Lee MS, Kim YM (2012) a-glucosidase and a -amylase inhibitory activities of phlorotannins from Eisenia bicyclis. J Sci Food Agric, 92, 2084-2090

24. Gao X, Bjor, L, Trajkovski V, Uggla M (2000) Evaluation of antioxidant activities of rosehip ethanol extracts in different test system. J Sci Food Agric, 80, 2021-2027

25. Lee S G, Yu MH, Lee S P, Lee IS (2008) Antioxidant activities and induction of apoptosis by methanol extracts from avocado. J Korean Soc Food Sci Nutr, 37, 269-275

26. Wang SY, Chang HN, Lin KT, Lo CP, Yang NS, Shyur LF (2003) Antioxidant properties and phytochemical characteristics of extracts from Lactucaindica. J Agric Food Chem, 26, 1506-1512

27. Re R, Pellegrini N, Proteggente A, Pannala A, Yang M, Rice-Evans C (1999) Antioxidant activity applying an improved ABTS radical cation decolorization assay. Free Radic Biol Med, 26, 1231-1237

28. Shin JA, Lee JH, Kim HS, Choi JH, Yoon KH (2012) Prevention of diabetes : a strategic approach for individural patients. Diabets Metab Res Rev, 28, 79-84

29. Bischoff $H$ (1995) The mechanism of alpha-glucosidase inhibition in the management of diabetes. Clin Invest 
Med, 18, 303-311

30. Nguyen MTT, Nguyen NTM, Nguyen HX, Huynh TNN, Min BS (2012) Screening of a-glucosidase inhibitory activity of Vietnamese medicinal plants : isolation of active principles from Oroxylum indicum Nat Prod Sci, $18,47-51$ 